\title{
, \\ COVID-19 Misinformation in Portuguese-Speaking Countries: Agreement with Content and Associated Factors
}

\author{
Álvaro Francisco Lopes de Sousa ${ }^{1,2, * \mathbb{D}}$, Guilherme Schneider ${ }^{2}$ (D) Herica Emilia Félix de Carvalho ${ }^{2}$ (D), \\ Layze Braz de Oliveira ${ }^{2}$, Shirley Verônica Melo Almeida Lima ${ }^{3} \mathbb{D}$, Anderson Reis de Sousa ${ }^{4}$, \\ Telma Maria Evangelista de Araújo ${ }^{5}$, Emerson Lucas Silva Camargo ${ }^{2} \mathbb{D}$, Mônica Oliveira Batista Oriá ${ }^{6}(\mathbb{D}$, \\ Carmen Viana Ramos ${ }^{7}$, Rodrigo Mota de Oliveira ${ }^{2}$, Camila Aparecida Pinheiro Landim Almeida ${ }^{8}$, \\ Andrêa Jacqueline Fortes Ferreira ${ }^{9}$, , Jules Ramon Brito Teixeira ${ }^{10} \mathbb{D}$, Iracema Lua ${ }^{11}$, \\ Fernanda de Oliveira Souza ${ }^{12}$, Tânia Maria de Araújo ${ }^{10} \mathbb{D}^{\mathbb{D}}$, Inês Fronteira ${ }^{1}$ and Isabel Amélia Costa Mendes $^{2}$
}

1 Global Health and Tropical Medicine (GHTM), Instituto de Higiene e Medicina Tropical, Universidade Nova de Lisboa, 1349-008 Lisbon, Portugal; ifronteira@ihmt.unl.pt

2 Human Exposome and Infectious Diseases Network (HEID), Ribeirão Preto College of Nursing, University of São Paulo, Ribeirao Preto 14040-902, Brazil; guilherme.schneider@usp.br (G.S.); hericacarvalho@usp.br (H.E.F.d.C.); layzebraz@usp.br (L.B.d.O.); lucmrg0@gmail.com (E.L.S.C.); rodrigoo@usp.br (R.M.d.O.); iamendes@eerp.usp.br (I.A.C.M.)

3 Center for Research in Collective Health, Federal University of Sergipe, Sao Cristovao 49100-000, Brazil; shirleymelo.lima@gmail.com

4 College of Nursing, Federal University of Bahia (UFBA), Salvador 40110-909, Brazil; anderson.sousa@ufba.br 5 Nursing Department, Federal University of Piauí, Teresina 64049-550, Brazil; telmaevangelista@gmail.com

6 Nursing Department, Federal University of Ceará, Fortaleza 60020-181, Brazil; profmonicaoria@gmail.com

7 Nursing Department, Centro Universitário UNINOVAFAPI/AFYA, Teresina 64073-505, Brazil; carmen.ramos@uninovafapi.edu.br

Citation: Sousa, Á.F.L.d.; Schneider, G.; Carvalho, H.E.F.d.; Oliveira, L.B.d.; Lima, S.V.M.A.; Sousa, A.R.d.; Araújo, T.M.E.d.; Camargo, E.L.S.; Oriá, M.O.B.; Ramos, C.V.; et al. COVID-19 Misinformation in Portuguese-Speaking Countries: Agreement with Content and Associated Factors. Sustainability 2022, 14, 235. https://doi.org/ $10.3390 /$ su14010235

Academic Editor: Lotfi Aleya

Received: 8 December 2021 Accepted: 23 December 2021 Published: 27 December 2021

Publisher's Note: MDPI stays neutral with regard to jurisdictional claims in published maps and institutional affiliations.

Copyright: (C) 2021 by the authors. Licensee MDPI, Basel, Switzerland. This article is an open access article distributed under the terms and conditions of the Creative Commons Attribution (CC BY) license (https:// creativecommons.org/licenses/by/ $4.0 /)$.
8 Institute of Health Sciences, Universidade Católica Portuguesa, 4099-002 Porto, Portugal; clalmeida@porto.ucp.pt

9 Data and Knowledge Integration Center for Health-CIDACS (Fiocruz-Bahia), Salvador 41745-715, Brazil; andreaferreiracv@gmail.com

10 Epidemiology Center, Feira de Santana State University, Feira de Santana 44036-900, Brazil; julesramon@gmail.com (J.R.B.T.); araujo.tania@uefs.br (T.M.d.A.)

11 Institute of Collective Health, Federal University of Bahia, Salvador 40170-110, Brazil; iracemalua.enfermeira@gmail.com

12 Health, Education and Work Department, Federal University of Recôncavo da Bahia, Santo Antonio de Jesus 44380-000, Brazil; fernandasouza@ufrb.edu.br

* Correspondence: sousa.alvaromd@gmail.com

\begin{abstract}
In the wake of the COVID-19 pandemic, a complex phenomenon called the "infodemic" has emerged, compromising coping with the pandemic. This study aims to estimate the prevalence of agreement with misinformation about COVID-19 and to identify associated factors. A web survey was carried out in Portuguese-speaking countries in two stages: 1 . the identification of misinformation circulating in the included countries; 2 . a multicentric online survey with residents of the included countries. The outcome of the study was agreement or disagreement with misinformation about COVID-19. Multivariate analyzes were conducted using the Poisson regression model with robust variance, a logarithmic link function, and $95 \%$ confidence intervals. The prevalence of agreement with misinformation about COVID-19 was $63.9 \%$. The following factors increased the prevalence of this outcome: having a religious affiliation (aPR: 1.454, 95\% CI: 1.393-1.517), having restrictions on leisure (aPR: 1.230, 95\% CI: 1.127-1.342), practicing social isolation (aPR: 1.073, 95\% CI: 1.030-1.118), not avoiding agglomeration (aPR: 1.060, 95\% CI: 1.005-1.117), not seeking/receiving news from scientific sources (aPR: 1.153, 95\% CI: 1.068-1.245), seeking/receiving news from three or more non-scientific sources (aPR: 1.114, 95\% CI: 1.049-1.182), and giving credibility to news carried by people from social networks (aPR: 1.175, 95\% CI: 1.104-1.251). There was a high prevalence of agreement with misinformation about COVID-19. The quality, similarity, uniformity, and acceptance of the contents indicate a concentration of themes that reflect "homemade", simple, and easy methods to avoid infection by SARS-CoV-2, compromising decision-making and ability to cope with the disease.
\end{abstract}


Keywords: COVID-19; misinformation; pandemics; coronavirus infections; biomedical technology; health-related behaviors

\section{Introduction}

Coronavirus disease 2019 (COVID-19), a respiratory disease caused by the etiologic agent SARS-CoV-2, which is registered in 178 countries, has produced, or intensified what the WHO has called the "infodemic" [1], a term used to characterize the uncontrolled volume of information disseminated on a subject, including real and fake news. Excessive information makes it difficult to discern reliable sources and obtain safe guidelines for actions [2]. The convenience provided by the digital age, enhanced by social networks, caused a dispersion of content with a speed and unprecedented reach unseen previously in history. The rapid circulation of information without any type of prior checking or filtering allows the appearance of rumors, fake information, misinformation, and even false manipulated information with dubious intent (disinformation) [3-6]. Similar to an epidemic, false information and news are spreading with the capacity to produce diverse forms of damage, as observed with the spread of the virus, which justifies the adopted term [7].

The massive spread of information can be illustrated by almost 20,000 scientific articles on the COVID-19 topic published on Google Scholar since the beginning of the pandemic, as well as by more than 360 million videos uploaded to YouTube ${ }^{\circledR}$ in a single month using the terms "COVID-19" and "COVID 19", and more than 500 million monthly tweets related to the terms "coronavirus", "corona virus", "covid19", "covid-19", "covid_19", and "pandemic" on Twitter ${ }^{\circledR}[1]$.

The emergence of an immense amount of information compromises the strict control of the quality of posted and published content, leading to misinformation [3]. In the pandemic context, the uncertainties of the scenarios experienced and the fear of being affected, intensify the search for immediate guidance, comfort, or relief. Thus, due to this urgency, information is often accepted without the necessary dedication of people to an analysis of its contents, the careful evaluation of available evidence, and whether the information comes from a reliable source. Disinformation acquires the potential to be easily consumed, accepted, and propagated by significant sections of the population, according to personal or collective interests $[8,9]$.

With globalization and the rise of the digital age, misinformation started to break territorial boundaries and, when benefited by characteristics such as shared language between culturally different countries, it has its propagation maximized, potentiating the adoption of behaviors and attitudes that expand individual and collective risks, resulting in a harmful scenario during the pandemic. The dissemination of misinformation on social networks and other means of communication impacts confidence in institutions (government, industry, and science), and consequently reduces confidence in health systems [10].

Based on the need and importance of public health actions supported by solid scientific knowledge of the control of health crises, and considering the potential adverse impacts of disinformation on the global control of diseases, it is necessary to identify the magnitude of the agreement with misinformation about COVID-19 and to analyze the factors that can influence beliefs and operate acceptance or rejection of false information between people, countries, and cultures. This study aims to estimate the prevalence of agreement with misinformation about COVID-19 and to identify associated factors.

\section{Materials and Methods}

A multicentric online survey (web survey) was carried out with populations from seven countries whose official language is Portuguese: Portugal, Brazil, Angola, Cape Verde, Guinea-Bissau, Mozambique, and São Tomé and Príncipe.

The research was developed in two stages: 


\subsection{Step 1. Identification of the Main Fake News Digitally Transmitted in Portuguese}

In this step, a data mining technique was used. The social network used was Twitter, due to its privacy policy [11] that makes all tweets registered by its users public, allowing anyone to view and search through the application programming interfaces (APIs) supported by tools for monitoring and analyzing published content. Thus, an application was developed in NodeJS (https:/ / nodejs.org/ accessed on 7 December 2021) that interacts with the Twitter API to collect all messages published through the search filters and the base criteria defined for the study. The search was done on messages published only in Portuguese. In April and May 2020, around 10,000 Twitter messages (tweets) were collected and selected for analysis which contained at least one of the following hashtags: \#COVID-19, \#Coronavirus, and \#SARSCov-2. The terms should be mentioned in the same post, using uppercase or lowercase letters, and spelled without accentuation. Posts in other languages and retweets were excluded.

After selecting the sample, a pre-processing of data was carried out to improve the quality of the findings and increase the efficiency of the data mining process. The $\mathrm{R}$ software [12] was used due to its robust tools that make it possible to manipulate and organize the findings. We searched for the words most associated with the posts (for example, "garlic" and "COVID-19") and later, what was the most publicized news related to that word on the social network (for example: "garlic recipe with boiled water kills COVID-19"). As a result, a list of 21 false information (Supplementary Table S1) was identified and placed on a data collection form. In order to avoid mistrust on the part of the participants, and measurement bias, a real post was inserted for every seven examples of fake news.

\subsection{Step 2. Populational Online Survey}

The data collection was carried out between June and August 2020, when countries were already experiencing restrictive sanitary measures, social distancing, and quarantine to prevent the spread of SARS-CoV-2.

The participants were recruited using the snowball method adapted to the virtual environment. In this method, the participant himself is responsible for recruiting other participants with a similar profile through his social networks. Initially, to meet the requirements of this method, we randomly selected 30 people from Portugal and Brazil from a database of a previous studies about the COVID-19 pandemic. These people were the first participants and were called "seeds". To increase the generalizability of the study, this group included people from diverse locations in the countries (divided according to regions), with differing origins (native and immigrants), ethnicities (white and non-white), ages (young, adult, and older adults), and levels of education (elementary/high school, university education, and postgraduate). Concomitantly, to disseminate the study, we have used e-mail lists from universities that maintained interchange and partnership relations with each other (Institute of Hygiene and Tropical Medicine, University of São Paulo; Higher Institute of Health Sciences of Angola; and Higher Institute of Science and Technology of Mozambique). Information about the research was also published on the social network Facebook, aiming to enhance responses to the questionnaire.

\subsection{Population, Sample, and Eligibility Criteria}

The sample size necessary for conducting the study was calculated using the calculation for finite samples $\left(n=[\operatorname{EDFF} \times \mathrm{Np}(1-\mathrm{p})] /\left[\left(\mathrm{d}^{2} / \mathrm{Z}^{2}{ }_{1-\alpha / 2} \times(\mathrm{N}-1)+\mathrm{p} \times(1-\mathrm{p})\right]\right)\right.$ and the following parameters: total number of residents of the seven countries $(\mathrm{N}=286,165,991)$, incidence of $50 \%$ due to the lack of previous studies, accuracy of 3\%, correction for sampling design of 2, confidence level of $95 \%$, and $20 \%$ additional subjects due to possible losses and withdrawals, resulting in 2562 participants.

In total, 7083 people answered the questionnaire, of which 240 were excluded for not living in the selected countries, not speaking Portuguese, being aged under 18 years, or due to the presence of invalid answers in more than $50 \%$ of the questions. The final sample 
consisted of 6843 residents of the seven countries, which is a population greater than the estimated minimum, increasing the power of this study.

\subsection{Data Collection Instrument}

A structured questionnaire was developed by the authors based on the literature [13-17] and evaluated by a group of experts through successive Delphi rounds. The expert analysis covered the questionnaire's construct validity and its cultural and linguistic properties. The online questionnaire was hosted on a specific website that allowed for quick data collection in Brazilian and European Portuguese and only allowed one response via Internet Protocol (IP), that is, one response per electronic device, thus avoiding multiple entries by the same user and, consequently, selection biases [18,19].

The questionnaire was divided into four sections:

1. Sociodemographic data (place of birth; country, region/district, state and city where the subjects were currently living; time living in the country; number of people living with each subject; number of rooms in the subject's house; family income; age; gender identity; schooling; religion; and marital status);

2. Perception about the COVID-19 pandemic (fear, impact, and limitations experienced during the pandemic, and agreement with preventive measures and strategies to mitigate the virus), practices to prevent contact and spread of the virus, and COVID19 testing and test results;

3. Search and consumption of information/news about COVID-19, impact of information/news about COVID-19, actions taken based on information/news received about COVID-19;

4. Agreement with misinformation about COVID-19, assessed through a Likert scale with responses of strongly agree, agree, neutral, disagree, and strongly disagree.

Scientific sources were defined as those resulting from recommendations issued by scientific societies or the representatives of these societies. Official bodies were considered those linked to governments (such as the country's Ministry of Health) or internationally recognized organizations (such as the World Health Organization). Finally, high-circulation newspapers were defined as those that have existed for a long time in each country and are edited by large publishing groups. Low- or limited-circulation newspapers were defined as those that are relatively new and are considered as a "free press". The definitions mentioned above were made available to the respondents.

\subsection{Outcome}

The outcome of this study was agreement (strongly agree or agree) or disagreement (strongly disagree, disagree, or neutral) with at least one of the statements characterized by misinformation about COVID-19.

\subsection{Data Analysis}

The data were analyzed using the Statistical Package for the Social Sciences (SPPS) version 24.0 (SPSS Inc., Chicago, IL, USA).

The descriptive analysis included absolute and relative frequencies. Prevalence ratios were used to evaluate crude associations (bivariate analysis), and their statistical significance was tested using Pearson's Chi-square test and the Monte Carlo method, considering $p \leq 0.05$ the minimum significance value. Ninety-five percent confidence intervals were also established. Monte Carlo permutations were used to calculate $p$ values of independent variables presenting more than two categories of analysis to obtain a better statistical adjustment of the data.

All variables were previously analyzed to assess whether multicollinearity existed or not, following tolerance coefficients and VIF (variance inflation factor) parameters. Considering the high frequency of the reference outcome (agreement with misinformation about COVID-19 greater than 10\%), the measure of association from traditional logistic regression analyzes (odds ratio, OR) overestimates associations. Thus, we opted for the 
Poisson regression model with a robust variance estimation using a covariance matrix (generalized linear model) to estimate the prevalence ratio (PR), which, in turn, is the most appropriate measure for cross-sectional studies. A logarithmic link function and 95\% CI were also used $[20,21]$.

The selection of variables for the multivariate model was made based on the results of the bivariate analyzes, based on statistical significance ( $p$-value $\leq 0.05)$, theoretical relevance, or better adjustment conditions. The parameters observed for the best performance adopted the Akaike information criterion (AIC), log-likelihood, the omnibus test, and effect tests (type III) as references.

\subsection{Ethical and Legal Aspects}

The Institutional Review Boards of the countries in which the study was conducted approved the research project. All the participants signed a free and informed consent form before taking part in the study.

\section{Results}

From the 6843 participants considered eligible for the online survey, $4291(62.7 \%)$ resided in Brazil, 1299 (19.0\%) in Portugal, 414 (6.0\%) in Angola, 348 (5.1\%) in Mozambique, 268 (3.9\%) in Cape Verde, 155 (2.3\%) in São Tomé and Príncipe, and 68 (1\%) in Guinea-Bissau (results not shown in tables).

The prevalence of agreement with COVID-19 misinformation was 63.9\% (Supplementary Table S1). The multivariate regression identified important aspects that can influence agreement with COVID-19 misinformation in an integrated manner. Some factors increased the prevalence of agreement with COVID-19 misinformation: having a religious affiliation $(45 \%)$, having restrictions on leisure $(23 \%)$, practicing social isolation $(7 \%)$, and number of rooms in their residence (5\%). Not avoiding agglomerations by performing activities such as going to a bar/restaurant or to social events increased the acceptance of COVID-19 misinformation by $6 \%$.

The source of information influenced the acceptance of content with dubious information about COVID-19 in general. The lack of search for reliable sources increased the prevalence of agreement with misinformation about COVID-19 by 15\%, while the act of searching for unreliable sources or questionable sources increased the outcome by $6 \%$ (considering access to one to two sources) and by $14 \%$ (access to three or more sources). Besides this, giving credibility to news carried by people from social networks or by unofficial bodies, to the detriment of official bodies, increased the outcome of agreement with misinformation by $18 \%$ and $13 \%$, respectively (Table 1 ).

Table 1. Sociodemographic characteristics, variables related to the pandemic period, and bivariate and multivariate analysis of factors associated with the agreement with COVID-19 misinformation, 2020.

\begin{tabular}{|c|c|c|c|c|c|}
\hline Associated Factors & $\begin{array}{l}\text { Agreement with } \\
\text { COVID-19 } \\
\text { Misinformation }\end{array}$ & $p(\%)$ & $p$-Value & $\begin{array}{l}\text { Bivariate Analysis } \\
\text { PR (CI 95\%) }\end{array}$ & $\begin{array}{c}\text { Multivariate Analysis } \\
\text { aPR (CI 95\%) }\end{array}$ \\
\hline \multicolumn{6}{|c|}{ Sociodemographic characteristics } \\
\hline Country of residence & & & $<0.001$ & & \\
\hline Angola & 276 & 66.7 & & $1.312(1.203-1.431)$ & - \\
\hline Brazil & 2951 & 68.8 & & $1.354(1.278-1.433)$ & \\
\hline Cape Green & 151 & 56.3 & & $1.109(0.985-1.248)$ & \\
\hline Guinea Bissau & 35 & 51.5 & & $1.013(0.799-1.284)$ & \\
\hline Mozambique & 215 & 61.8 & & $1.216(1.102-1.342)$ & \\
\hline São Tomé and Príncipe & 82 & 52.9 & & $1.041(0.889-1.219)$ & \\
\hline Portugal & 660 & 50.8 & & 1.00 & \\
\hline Immigrant & & & $<0.001$ & & \\
\hline
\end{tabular}


Table 1. Cont.

\begin{tabular}{|c|c|c|c|c|c|}
\hline Associated Factors & $\begin{array}{l}\text { Agreement with } \\
\text { COVID-19 } \\
\text { Misinformation }\end{array}$ & $p(\%)$ & $p$-Value & $\begin{array}{l}\text { Bivariate Analysis } \\
\text { PR (CI 95\%) }\end{array}$ & $\begin{array}{l}\text { Multivariate Analysis } \\
\text { aPR (CI 95\%) }\end{array}$ \\
\hline Yes & 443 & 53.0 & & 1.00 & - \\
\hline No & 3297 & 65.4 & & $1.234(1.154-1.318)$ & \\
\hline Marital status & & & 0.749 & & \\
\hline In a relationship & 2860 & 64.0 & & 1.00 & - \\
\hline Single & 1510 & 63.6 & & $0.994(0.957-1.032)$ & \\
\hline Age group & & & 0.228 & & \\
\hline 18 to 29 years & 1.507 & 64.6 & & $0.990(0.941-1.041)$ & - \\
\hline 30 to 49 years & 2071 & 62.9 & & $0.963(0.918-1.012)$ & \\
\hline 50 years and older & 792 & 65.2 & & 1.00 & \\
\hline Number of rooms in the residence & & & $<0.001$ & & \\
\hline Less than or equal to 3 & 862 & 57.7 & & 1.00 & 1.00 \\
\hline Greater than 3 & 3.508 & 65.6 & & $1.138(1.085-1.193)$ & $1.052(1.001-1.106)$ \\
\hline Number of people in the residence & & & 0.058 & & \\
\hline Less than or equal to 3 & 2982 & 63.1 & & 1.00 & - \\
\hline Greater than 3 & 1388 & 65.5 & & $1.038(0.999-1.078)$ & \\
\hline Education & & & $<0.001$ & & \\
\hline Elementary/High School & 844 & 59.9 & & $0.909(0.865-0.955)$ & - \\
\hline University education & 1452 & 63.4 & & $0.963(0.925-1.002)$ & \\
\hline Postgraduate level & 2037 & 65.9 & & 1.00 & \\
\hline Religious affiliation & & & $<0.001$ & & \\
\hline Yes & 2732 & 75.5 & & $1.488(1.431-1.546)$ & $1.454(1.393-1.517)$ \\
\hline No & 1638 & 50.8 & & 1.00 & 1.00 \\
\hline \multicolumn{6}{|l|}{ Coping strategies } \\
\hline Social isolation time & & & $<0.001$ & & \\
\hline Not in isolation & 873 & 57.8 & & $0.904(0.856-0.955)$ & $0.973(0.922-1.027)$ \\
\hline Less than 90 days & 921 & 68.7 & & $1.095(1.049-1.142)$ & $1.073(1.030-1.118)$ \\
\hline More than 90 days & 537 & 70.5 & & 1.00 & 1.00 \\
\hline $\begin{array}{l}\text { Agglomeration avoidance (bars, restaurants, } \\
\text { and social events) }\end{array}$ & & & 0.003 & & \\
\hline Yes & 3781 & 63.2 & & 1.00 & 1.00 \\
\hline No & 589 & 68.5 & & $1.084(1.032-1.139)$ & $1.060(1.005-1.117)$ \\
\hline Environments/objects sanitization & & & 0.037 & & \\
\hline Yes & 3137 & 63.1 & & 1.00 & - \\
\hline No & 1233 & 65.8 & & $1.043(1.003-1.084)$ & \\
\hline Postponement of travels & & & 0.385 & & \\
\hline Yes & 2.972 & 63.5 & & 1.00 & - \\
\hline No & 1398 & 64.6 & & $1.017(0.979-1.056)$ & \\
\hline Use of masks for individual protection & & & 0.004 & & \\
\hline Yes & 4.275 & 64.1 & & 1.00 & - \\
\hline No & 95 & 53.7 & & $1.013(0.908-1.129)$ & \\
\hline Agreement with the need for social distancing & & & 0.020 & & \\
\hline Yes & 4216 & 63.7 & & 1.00 & - \\
\hline No & 75 & 75.0 & & $1.177(1.049-1.320)$ & \\
\hline
\end{tabular}


Table 1. Cont.

\begin{tabular}{|c|c|c|c|c|c|}
\hline Associated Factors & $\begin{array}{l}\text { Agreement with } \\
\text { COVID-19 } \\
\text { Misinformation }\end{array}$ & $p(\%)$ & $p$-Value & $\begin{array}{l}\text { Bivariate Analysis } \\
\text { PR (CI 95\%) }\end{array}$ & $\begin{array}{l}\text { Multivariate Analysis } \\
\text { aPR (CI 95\%) }\end{array}$ \\
\hline $\begin{array}{l}\text { Agreement with the strategies adopted by the } \\
\text { Government to fight COVID-19 }\end{array}$ & & & 0.032 & & \\
\hline Yes & 913 & 66.5 & & 1.00 & - \\
\hline No & 2662 & 63.4 & & $0.952(0.911-0.995)$ & \\
\hline \multicolumn{6}{|l|}{$\begin{array}{l}\text { Consumption, confidence, and attitudes } \\
\text { towards COVID-19 news }\end{array}$} \\
\hline $\begin{array}{l}\text { Searched or received news from scientific } \\
\text { sources }\end{array}$ & & & 0.002 & & \\
\hline No & 201 & 73.9 & & $1.170(1.083-1.264)$ & $1.153(1.068-1.245)$ \\
\hline Yes, from 1 to 2 sources & 2654 & 63.6 & & $1.007(0.970-1.047)$ & $1.050(1.008-1.095)$ \\
\hline Yes, from 3 or more sources & 1.515 & 63.2 & & 1.00 & 1.00 \\
\hline $\begin{array}{l}\text { Searched or received news from non-scientific } \\
\text { sources }\end{array}$ & & & $<0.001$ & & \\
\hline No & 1562 & 61.0 & & 1.00 & 1.00 \\
\hline Yes, from 1 to 2 sources & 1878 & 64.6 & & $1.133(1.069-1.200)$ & $1.064(1.022-1.109)$ \\
\hline Yes, from 3 or more sources & 493 & 69.1 & & $1.058(1.016-1.103)$ & $1.114(1.049-1.182)$ \\
\hline Gave credit to news published by: & & & $<0.001$ & & \\
\hline Official bodies & 3516 & 62.0 & & 1.00 & 1.00 \\
\hline $\begin{array}{l}\text { People from social networks (family, friends, } \\
\text { and acquaintances) }\end{array}$ & 340 & 77.3 & & $1.247(1.181-1.317)$ & $1.175(1.104-1.251)$ \\
\hline Unofficial bodies & 216 & 66.7 & & $1.076(0.994-1.165)$ & $1.134(1.047-1.229)$ \\
\hline $\begin{array}{l}\text { Frequency in which you receive or search for } \\
\text { news about COVID-19 }\end{array}$ & & & 0.033 & & \\
\hline Daily & 2440 & 63.3 & & $0.924(0.873-0.978)$ & - \\
\hline Weekly & 1476 & 63.5 & & $0.928(0.874-0.985)$ & \\
\hline Rarely/never & 454 & 68.5 & & 1.00 & \\
\hline Impact of news on preventive attitudes & & & $<0.001$ & & \\
\hline None/low impact & 705 & 68.1 & & $1.078(1.030-1.129)$ & - \\
\hline Medium/high impact & 3665 & 63.1 & & 1.00 & \\
\hline $\begin{array}{l}\text { Frequency in which you have made decisions } \\
\text { based on news from low-circulation sources }\end{array}$ & & & $<0.001$ & & \\
\hline Never & 3518 & 62.7 & & 1.00 & \\
\hline 1 or more times & 852 & 68.9 & & $1.192(1.099-1.198)$ & - \\
\hline \multicolumn{6}{|l|}{$\begin{array}{l}\text { Repercussions of the pandemic on the daily } \\
\text { life }\end{array}$} \\
\hline $\begin{array}{l}\text { Do you fear the repercussions of the pandemic } \\
\text { in your future life? }\end{array}$ & & & 0.019 & & \\
\hline Yes & 3870 & 64.4 & & 1.00 & - \\
\hline No & 427 & 60.0 & & $0.931(0.874-1.991)$ & \\
\hline $\begin{array}{l}\text { Do you feel unmotivated/stressed during the } \\
\text { pandemic? }\end{array}$ & & & 0.006 & & \\
\hline Yes & 3.795 & 64.5 & & $1.077(1.019-1.138)$ & - \\
\hline No & 575 & 59.9 & & 1.00 & \\
\hline $\begin{array}{l}\text { Do you know someone who has had } \\
\text { COVID-19 or died from the disease? }\end{array}$ & & & 0.087 & & \\
\hline Yes & 2333 & 64.8 & & 1.00 & - \\
\hline No & 2037 & 62.8 & & $0.969(0.935-1.005)$ & \\
\hline Restrictions on leisure & & & 0.015 & & \\
\hline
\end{tabular}


Table 1. Cont.

\begin{tabular}{|c|c|c|c|c|c|}
\hline Associated Factors & $\begin{array}{l}\text { Agreement with } \\
\text { COVID-19 } \\
\text { Misinformation }\end{array}$ & $p(\%)$ & $p$-Value & $\begin{array}{c}\text { Bivariate Analysis } \\
\text { PR (CI 95\%) }\end{array}$ & $\begin{array}{c}\text { Multivariate Analysis } \\
\text { aPR (CI 95\%) }\end{array}$ \\
\hline Yes & 142 & 71.2 & & $1.133(1.037-1.238)$ & $1.230(1.127-1.342)$ \\
\hline No & 4228 & 63.6 & & 1.00 & 1.00 \\
\hline Restriction on access to family/friends & & & 0.220 & & \\
\hline Yes & 3638 & 64.2 & & $1.030(0.981-1.082)$ & - \\
\hline No & 732 & 62.3 & & 1.00 & \\
\hline Restriction on access to essential goods & & & 0.251 & & \\
\hline Yes & 585 & 65.6 & & $1.031(0.980-1.085)$ & - \\
\hline No & 3.785 & 63.6 & & 1.00 & \\
\hline Restriction on access to professional activities & & & 0.021 & & \\
\hline Yes & 1694 & 65.6 & & $1.044(1.007-1.083)$ & - \\
\hline No & 2676 & 62.8 & & 1.00 & \\
\hline Restriction on access to protection measures & & & 0.008 & & \\
\hline Yes & 657 & 60.3 & & $0.935(0.888-0.985)$ & - \\
\hline No & 3.713 & 64.5 & & 1.00 & \\
\hline
\end{tabular}

\section{Discussion}

Countries historically close in geography, culture, religion, and language may share content, reinforcing misinformation about COVID-19 in their territories. Since the countries in which the study was undertaken have different populations but share a common language (Portuguese), the content characterized as misinformation about COVID-19 consumed in these territories was strongly similar and accepted in a uniform manner. Given the above, the diffusion of misinformation about COVID-19 probably can overcome terrestrial and cultural barriers and can cross countries and continents, negatively affecting the fight against COVID-19 in a global health perspective. A uniformity of the content consumed by the participants was found, and focused on homemade, simple, and easy methods to avoid infection by SARS-CoV-2. Consequently, people start to face the virus using the fallacy of easy protection, which justifies the abandonment of other protections and mitigation measures that require higher levels of effort or commitment.

Among the variables related with agreement with misinformation about COVID-19 (presented by approximately two-thirds of the participants) were social characteristics (religion affiliation and housing), attitudes and perceptions concerning social distancing (practice of isolation, not avoiding agglomerations, and leisure restrictions), source of information (traditional/high-circulation newspapers versus non-traditional/low-circulation newspapers), and the emitter of the content (scientific or non-scientific sources, and people from social networks).

Among the factors mentioned above, religious affiliation stood out. The deaths and disruptions caused by the COVID-19 pandemic may make people turn to religious groups. In times of crisis, faith can be a source of personal comfort and resilience, uniting communities searching for strength to go through these challenging times. On the other hand, as COVID-19 advances worldwide, the misinformation role of religious leaders also has advanced, especially in countries in Africa and Latin America [22-24]. A study [25] shows that disinformation about the new coronavirus is significant in Latin-American Christian communities. Due to their reliable and hegemonic position, some religious leaders legitimize potentially dangerous ideas for the general public through cults, independent newspapers, and social media, undermining virus mitigation actions, fostering skeptical positions regarding restrictive measures and the establishment of prevention strategies. 
This scenario benefits from healthism, a belief system in which individuals see themselves as mainly or solely responsible for their health. While on one hand these individuals may become rational and informed, on the other hand they can present a strong distrust towards medical authorities and conventional medicine, making people more likely to resort to "alternative truths" and explanations that lack theoretical or empirical support [26]. In general, they come to defend negative positions that endorse a set of actions that, at best, are innocuous, but when amplified by influence groups, have dangerous collective impacts.

The COVID-19 pandemic is a milestone for humanity, and, historically, changes have been the target of resistance, especially when they affect our beliefs and lifestyles. For this reason, limitations related to measures of social distancing (isolation, experiencing restrictions, access to leisure, and agglomeration avoidance) have impacted the prevalence of agreement with misinformation. Studies $[27,28]$ indicate that as the pandemic state is extended, the population's willingness to adhere to non-pharmacological measures decreases. On the other hand, there is an increase in the willingness to use alternative treatments that lack scientific support, as they can be less painful and cause fewer complications than traditional ones, which may explain the popularity of misinformation about "magic solutions".

The search for information in the face of imminent danger can reflect an adaptive behavior, which allows us to make informed decisions about how to stay safe. Regarding this, data [25-30] point out that the very context of COVID-19, with restrictions, lockdowns, and social distancing, enhances the sharing of information through social media, regardless of the quality of that information [30-35]. When such news has a tone of "novelty" or brings a "simple and magical solution", people tend to be more receptive and sharing increases. For this reason, a study [36] estimates that fake news spreads $70 \%$ faster than real news and reaches more audiences in less time.

In this sense, the COVID-19 pandemic reinforces the contemporary behavioral tendency to seek information that confirms some beliefs in a convenient manner, a phenomenon known as confirmatory bias. This effect is particularly strong in matters of intense emotional charge and deeply held beliefs, as in the present moment.

On this aspect, it is evident that not only the information itself is decisive for misinformation, but also the origin of the source and who propagates it. Information sources are related to the reader's need for information and also their perception of trust, which is why the type of the information source (non-traditional) and the increased consumption of non-scientific sources (news transmitted by unreliable sources and people from social networks) have raised the prevalence of agreement with misinformation in the present study. False information tends to present a unilateral narrative with a simple rumor from a theoretically "reliable" source to foster the "facts", opinions, and points of view presented in the news. Factors such as lack of time to consume and analyze the origin of the news have interfered with the authentication of fake news, with subsequent sharing $[37,38]$.

Among the biggest social media platforms, WhatsApp is a tool that allows the sharing of a great volume of disinformation. Twitter and Facebook have guidelines and rules that restrict the spread of fake news, such as warnings or causing the publication to be deleted [38,39]. According to Agência Brasil [40], in April 2020, the beginning of the coronavirus pandemic in Brazil, $73.7 \%$ of fake news circulated through the WhatsApp application. The excess of information and fake information disseminated on social media can make people experience two types of decision-making: one involves the indiscriminate use of so-called preventive measures without scientific scrutiny, and the other involves the refusal of scientifically proven information [41,42].

Combating the spread of misinformation is extremely necessary, requires multidisciplinary approaches, and increasingly sophisticated initiatives. Global internet and social media companies such as Google [43], Whatsapp [42], Facebook [44], and Twitter [45] have launched initiatives that allow users to ask questions and check the veracity of some information, and even machine learning algorithms to detect fake-news advertising and other misinformation has been used. The scientific community has also been working to 
fight against misinformation related to COVID-19, using surveillance systems to track the infodemic, analyzing false news, alternative, or invalid treatments and the dissemination of unfounded rumors in online media and social networks. Governments and organized civil society must partner with scientists, internet companies, and the media so that global initiatives are locally adapted and can bring messages accessible to the populations of their territories.

This research has some limitations. The sample was recruited by convenience sampling, which may not have been the best method for recruiting a representative sample of the countries' populations. Although we used a large sample size and strategies to increase the generalization of the data, such as the use of "seeds" and methods to increase the diversity of the sample, we have observed a concentration of young people and young adults in the sample. Thus, the data cannot be generalized for the general Portuguese-speaking populations. In addition, although nine countries officially speak Portuguese, we only managed responses from seven of them.

We included in this research countries with very different levels of socioeconomic development from each other, especially with regard to access to the technological resources necessary to participate in the study. This may have strongly affected our study and may have worked as a criterion for selecting specific groups. This is an important problem in web surveys and must be considered.

Despite these limitations, this study has many positive points. The first point to be highlighted is its scope, involving a large sample of seven Portuguese-speaking countries. Although the largest proportion of the participants consisted of Brazilians, it included an important contingent of residents from other countries. The high level of agreement with misinformation found characterizes a problem that has already crossed national barriers and, thus, needs to be tackled globally. Another strong point is the wide set of factors analyzed that allowed for a scan of variables potentially related to the problem under investigation. The results pointed out factors that need special attention in the fight against misinformation.

\section{Conclusions}

Our findings showed that in Portuguese-speaking countries, in the context of the COVID-19 pandemic, the infodemic is accelerating and perpetuating misinformation, seemingly expanding at the same pace as content production. The large amount of content available is affecting decision-making processes for dealing with the pandemic, as people expect immediate responses and do not seem to spend enough time to carefully analyze the scientific evidence. It is essential and urgent that governments create efficient and accessible institutional mechanisms capable of interrupting this dangerous cycle. In addition, they must create bold, intelligent, and safe strategies to map the content of fake news that is produced and disseminated, making it possible to recognize the intentions and targets of misinformation, and with that, prepare populations to fight fake news and get involved in collective counter-disinformation actions.

We cannot ignore the impact that misinformation has on the current panorama of the COVID-19 pandemic, especially in Latin America and Africa, where conflicting information also comes from institutional offices. In this sense, it is necessary to think about digital and informational health literacy, empowering populations to recognize fake information and providing helpful tools for that purpose.

It is necessary to increase communication efforts for groups more vulnerable to disinformation. To do so, there must be a review of communication strategies through health education and communication actions that approach the reality experienced by individuals, (re)building the link between scientific knowledge and popular knowledge, allowing the construction of shared knowledge that is meaningful for the population.

Supplementary Materials: The following supporting information can be downloaded at https: / / www.mdpi.com/article/10.3390/su14010235/s1, Table S1: misinformation identified from twitter. 


\begin{abstract}
Author Contributions: Conceptualization, Á.F.L.d.S., I.F. and I.A.C.M.; data curation, I.L., L.B.d.O., T.M.E.d.A., E.L.S.C., M.O.B.O., T.M.d.A. and I.A.C.M.; formal analysis, Á.F.L.d.S., J.R.B.T., G.S., A.J.F.F., H.E.F.d.C., S.V.M.A.L., I.L., F.d.O.S., T.M.d.A. and I.F.; funding acquisition, Á.F.L.d.S., I.F. and I.A.C.M.; investigation, Á.F.L.d.S., J.R.B.T., S.V.M.A.L., A.R.d.S., M.O.B.O., T.M.E.d.A., I.A.C.M., L.B.d.O., H.E.F.d.C., I.A.C.M., C.V.R., C.A.P.L.A. and R.M.d.O.; methodology, Á.F.L.d.S., G.S., T.M.E.d.A., E.L.S.C., T.M.E.d.A. and I.F.; project administration, A.J.F.F., L.B.d.O. and A.R.d.S.; writing—original draft, Á.F.L.d.S., J.R.B.T., S.V.M.A.L., A.R.d.S., M.O.B.O., T.M.E.d.A., I.A.C.M., L.B.d.O., H.E.F.d.C., I.A.C.M., C.V.R., C.A.P.L.A. and R.M.d.O.; writing-review and editing, Á.F.L.d.S., J.R.B.T., S.V.M.A.L., A.R.d.S., M.O.B.O., T.M.E.d.A., I.A.C.M., T.M.d.A. and I.F. All authors have read and agreed to the published version of the manuscript.
\end{abstract}

Funding: FCT for funds to GHTM-UID/004413-2020.

Institutional Review Board Statement: The study was conducted according to the guidelines of the Declaration of Helsinki, and approved by the Brazilian National Research Ethics Council (Conselho Nacional de Ética em Pesquisa-CONEP, in Portuguese, (protocol code 31023020.8.0000.0008 and 01/06/2020 of approval).

Informed Consent Statement: Informed consent has been obtained online from all the participants to publish this paper.

Data Availability Statement: Data connected to this research are available from the corresponding author under request (AFLS).

Conflicts of Interest: The authors declare no conflict of interest.

\title{
References
}

1. WHO. Infodemic-WHOI World Health Organization. 2020. Available online: https://www.who.int/health-topics/infodemic\# tab=tab_1 (accessed on 7 December 2021).

2. Garcia, L.P.; Duarte, E. Infodemic: Excess quantity to the detriment of quality of information about COVID-19. Epidemiol. Serv. Saúde 2020, 29, e2020186. [CrossRef]

3. Wardle, C.; Derakhshan, H. Information Disorder: Council of Europe Report. 2017. Available online: https://tverezo.info/wpcontent/uploads/2017/11/PREMS-162317-GBR-2018-Report-desinformation-A4-BAT.pdf (accessed on 7 December 2021).

4. Mejova, Y.; Kalimeri, K. Advertisers Jump on Coronavirus Bandwagon: Politics, News, and Business. arXiv 2020, arXiv:2003.00923v1.

5. Shimizu, K. 2019-nCoV, fake news, and racism. Lancet 2020, 395, 685-686. [CrossRef]

6. Thomas, Z. Misinformation on Coronavirus Causing 'Infodemic'. 2020. Available online: https://www.bbc.com/news/ technology-51497800 (accessed on 9 March 2020).

7. World Health Organisation. How to Report Misinformation Online. 2020. Available online: https://www.who.int/campaigns / connecting-the-world-to-combat-coronavirus/how-to-report-misinformation-online (accessed on 27 April 2021).

8. The Lancet. COVID-19 in Brazil: "So what?". Lancet 2020, 395, 1461. [CrossRef]

9. Galhardi, C.P.; Freire, N.P.; Minayo, M.C.S.; Fagundes, M.C.M. Fact or Fake? An analysis of disinformation regarding the COVID-19 pandemic in Brazil. Ciênc. Saúde Coletiva 2020, 25, 4201-4210. [CrossRef] [PubMed]

10. Swire-Thompson, B.; Lazer, D. Public Health and Online Misinformation: Challenges and Recommendations. Annu. Rev. Public Health 2020, 41, 433-451. [CrossRef] [PubMed]

11. Twitter: Privacy Policy. Twitter. Available online: https://twitter.com/en/privacy (accessed on 7 December 2021).

12. The R Project for Statistical Computing. Available online: https:/ /www.r-project.org/ (accessed on 7 December 2021).

13. Bastani, P.; Hakimzadeh, S.M.; Bahrami, M.A. Designing a conceptual framework for misinformation on social media: A qualitative study on COVID-19. BMC Res. Notes 2021, 14, 408. [CrossRef] [PubMed]

14. Apuke, O.D.; Omar, B. Fake news and COVID-19: Modelling the predictors of fake news sharing among social media users. Telemat. Inform. 2021, 56, 101475. [CrossRef]

15. Roozenbeek, J.; Schneider, C.R.; Dryhurst, S.; Kerr, J.; Freeman, A.L.J.; Recchia, G.; van der Bles, A.M.; van der Linden, S. Susceptibility to misinformation about COVID-19 around the world. R. Soc. Open Sci. 2020, 7, 201199. [CrossRef] [PubMed]

16. Kouzy, R.; Abi Jaoude, J.; Kraitem, A.; El Alam, M.B.; Karam, B.; Adib, E.; Zarka, J.; Traboulsi, C.; Akl, E.W.; Baddour, K. Coronavirus Goes Viral: Quantifying the COVID-19 Misinformation Epidemic on Twitter. Cureus 2020, 12, e7255. [CrossRef] [PubMed]

17. Shahi, G.K.; Dirkson, A.; Majchrzak, T.A. An exploratory study of COVID-19 misinformation on Twitter. Online Soc. Netw. Media 2021, 22, 100104. [CrossRef]

18. de Sousa, A.; de Oliveira, L.; Queiroz, A.; de Carvalho, H.; Schneider, G.; Camargo, E.; de Araújo, T.; Brignol, S.; Mendes, I.; Fronteira, I.; et al. Casual Sex among Men Who Have Sex with Men (MSM) during the Period of Sheltering in Place to Prevent the Spread of COVID-19. Int. J. Environ. Res. Public Health 2021, 18, 3266. [CrossRef] 
19. Chone, J.S.; Lima, S.V.M.A.; Fronteira, I.; Mendes, I.A.C.; Shaaban, A.N.; Martins, M.D.R.O.; Sousa, Á.F.L. Factors associated with chemsex in Portugal during the COVID-19 pandemic. Rev. Lat. Am. Enfermagem. 2021, 29, e3474. [CrossRef]

20. Coutinho, L.M.S.; Scazufca, M.; Menezes, P.R. Methods for Estimating Prevalence Ratios in Cross-Sectional Studies. Rev. Saúde Pública 2008, 42, 992-998. Available online: http:/ / www.scielo.br/scielo.php?script=sci_arttext\&pid=S0034-89102008000600003\& lng=en (accessed on 28 April 2021). [CrossRef] [PubMed]

21. Francisco, P.M.S.B.; Donalisio, M.R.; Barros, M.B.D.A.; Cesar, C.L.G.; Carandina, L.; Goldbaum, M. Association Measures in Crosssectional Studies with Complex Sampling: Odds Ratio and Prevalence Ratio. Rev. Bras. Epidemiol. 2008, 11, $347-355$. Available online: http:/ / www.scielo.br/sc(accessedont\&pid=S1415-790X2008000300002\&lng=en (accessed on 28 April 2021). [CrossRef]

22. Alimardani, M.; Elswah, M. Online Temptations: COVID-19 and Religious Misinformation in the MENA Region. Soc. Media Soc. 2020, 6, 2056305120948251. [CrossRef] [PubMed]

23. BBC. Coronavirus: Fake News Wey Don Spread about COVID-19 for Africa. 2020. Available online: https://www.bbc.com/ pidgin/tori-51764759 (accessed on 27 April 2021).

24. DW Made for Mindos. American Evangelicals and the Resistance to COVID Vacines. 2020. Available online: https://www.dw. com/en/american-evangelicals-and-the-resistance-to-covid-vaccines/a-55957915 (accessed on 27 April 2021).

25. Bandeira, O.; Carranza, B. Reactions to the Pandemic in Latin America and Brazil: Are Religions Essential Services? Int. J. Lat. Am. Relig. 2020, 4, 170-193. [CrossRef]

26. Greenhalgh, T.; Wessely, S. "Health for me": A sociocultural analysis of healthism in the middle classes. Br. Med. Bull. 2004, 69, 197-213. [CrossRef]

27. Martarelli, C.S.; Wolff, W. Too bored to bother? Boredom as a potential threat to the efficacy of pandemic containment measures Humanit. Soc. Sci. Commun. 2020, 7, 28. [CrossRef]

28. Wolff, W.; Martarelli, C.S.; Schüler, J.; Bieleke, M. High Boredom Proneness and Low Trait Self-Control Impair Adherence to Social Distancing Guidelines during the COVID-19 Pandemic. Int. J. Environ. Res. Public Health 2020, 17, 5420. [CrossRef]

29. Tsao, S.F.; Chen, H.; Tisseverasinghe, T.; Yang, Y.; Li, L.; Butt, Z.A. What social media told us in the time of COVID-19: A scoping review. Lancet Digit. Health 2021, 3, e175-e194. [CrossRef]

30. Bento, A.I.; Nguyen, T.; Wing, C.; Lozano-Rojas, F.; Ahn, Y.Y.; Simon, K. Evidence from internet search data shows informationseeking responses to news of local COVID-19 cases. Proc. Natl. Acad. Sci. USA 2020, 117, 11220-11222. [CrossRef] [PubMed]

31. Tech Crunch. Nielsen Explains How COVID-19 Could Impact Media Usage across the US. 2020. Available online: https:/ / techcrunch.com/2020/03/17/nielsen-explains-how-covid-19-could-impact-mediausage-across-the-u-s/ (accessed on 22 March 2021).

32. Newsweek. Americans Binged on Video Games, Shrugged off Social Media as Pandemic Restrictions Kicked in, Verizon Says. 2020. Available online: https:/ / www.newsweek.com/instead-working-home-most-americans-are-using-self-isolation-catchvideo-games-1493129 (accessed on 22 March 2021).

33. GWI. Coronavirus: How Consumers Are Actually Reacting. 2020. Available online: https://blog.globalwebindex.com/trends/ coronavirusand-consumers/ (accessed on 22 March 2021).

34. eMarketer. The Biggest Business Impacts of the Coronavirus Pandemic. 2020. Available online: https://www.emarketer $\mathrm{com} /$ content/the-biggestbusiness-impacts-of-the-coronavirus-pandemic-accordingto-business-insider-intelligence (accessed on 27 April 2021).

35. Wiederhold, B.K. Social Media Use during Social Distancing. Cyberpsychol. Behav. Soc. Netw. 2020, 23, 275-276. [CrossRef] [PubMed]

36. Vosoughi, S.; Roy, D.; Aral, S. The spread of true and false news online. Science 2018, 6380, 1146-1151. [CrossRef] [PubMed]

37. Talwa, S.; Dhir, A.; Singh, D.; Virk, G.; Salo, J. Sharing of fake news on social media: Application of the honeycomb framework and the third-person effect hypothesis. J. Retail. Consum. Serv. 2020, 57, 102197. [CrossRef]

38. Scherer, L.D.; Pennycook, G. Who Is Susceptible to Online Health Misinformation? Am. J. Public Health 2020, 110, S276-S277. [CrossRef]

39. Klein, E. Communicational logics of the fake news circulation about Covid-19 on WhatsApp. Rizoma 2020, 8, 26-48. [CrossRef]

40. Nitahara, A. Agência Brasil. WhatsApp é a Principal Rede de Disseminação de Fake News Sobre COVID-19. 2020. Available online: https:/ /agenciabrasil.ebc.com.br/geral/noticia/2020-04/whatsapp-e-principal-rede-de-disseminacao-de-fake-newssobre-covid-19 (accessed on 27 April 2021).

41. Lemos, A.; Oliveira, F. Fake news sharing on Whatsapp: A study considering third person effects perception. Comun. Soc. 2020, 42, 193-227.

42. WhatsApp IFCN Fact Checking Organizations on WhatsApp. Available online: https://faq.whatsapp.com/general/ifcn-factchecking-organizations-on-whatsapp/?lang=fb (accessed on 7 December 2021).

43. Google Find Fact Checks in Search Results-Google Search Help. Available online: https://support.google.com/websearch/ answer /7315336?hl=en (accessed on 7 December 2021).

44. Facebook Working to Stop Misinformation and False News. Available online: https://www.facebook.com/formedia/blog/ working-to-stop-misinformation-and-false-news (accessed on 7 December 2021).

45. BBC. Twitter Works with News Sites to Tackle Disinformation. Available online: https://www.bbc.com/news/business-58065463 (accessed on 7 December 2021). 